\title{
Characteristics Of The Unemployed In Canada: Leavers, Losers And Layoffs
}

Nita N. Chhinzer, University of Guelph, Canada

Khaldoun I. Ababneh, American University in Dubai, Dubai

\begin{abstract}
This research identifies the need to disaggregate unemployed persons into job leaver, job loser and job layoff categorizations. Multinominal logit regression on Labor Force Survey data $(n=38,546)$ confirms that demographic, human capital and work-related variables account for almost a third of the variance in likelihood to fall into the disaggregated unemployment categories in Canada.
\end{abstract}

Keywords: unemployment; turnover; layoff; dismissal; termination; resignation; employee exits; labor force movement

\section{INTRODUCTION}

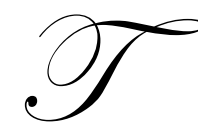

here has been much written about profiling the labor force in North America (Cappelli 2005; Aaronson et al. 2006; Juhn and Potter 2006; Van Horn 2006; Panagiotidis and Pelloni 2007). Significantly less has been written about the characteristics of the unemployed. Of this, the majority of research treats unemployed persons as a homogenous group (Aaronson et al. 2006; Autor et al. 2006; Riley and Young 2007). Traditionally, researchers have modelled job movers into one undifferentiated category when modeling the job mobility decision (Borjas 1981; Simpson 1990; Kidd 1991). The research that attempts to understand micro level differences in unemployed persons focus almost exclusively on economic aspects and is significantly dated (Borjas 1981; Hamermesh 1989; Farber and Hall 1993; Kidd 1994; Farber 1997; Picot et al. 1998; Hanisch 1999). Additionally, these studies assess antecedents and outcomes of unemployment using job leaver (quits) or job layoff categories, with no consideration for the job loser (dismissals) category. This paper updates and modifies existing research on individual level differences based on categorizations of unemployment in three significant ways.

First, this research treats the unemployed group as non-homogenous. Rather than comparing employed and unemployed persons, we identify individual level factors correlated with the likelihood to belong to the job leaver (quit), job loser (dismissal or permanent layoff) or job layoff category (temporary layoff) by assessing Labor Force Survey (LFS) data collected over a five year period. We use multinomial logit regression analysis on a sample size of 38,546 individuals to analyze unemployed persons based on causes of unemployment.

Second, we examine the Canadian labor force. To date, empirical evidence from Canada using a distinction of types of unemployment has been significantly hindered by the lack of data. Thus, only a limited number of studies are available exploring distinct categories of unemployment in Canada (McLaughlin 1991; Kidd 1994; Picot et al. 1998). This research extends beyond existing research to focus on disaggregating unemployment within the Canadian realm.

Third, we use demographic, human capital and work-related variables to support the notion that unemployment via job leaver, job layoff and job losers categories results in different profiles of unemployed persons, when compared with a control group of job stayers (individuals who did not change jobs in the survey period). This extends existing research which is focused almost exclusively on the economic perspectives of unemployment.

The primary contribution of this paper is to suggest that we must disaggregate the unemployed group to 
help us understand the pattern of unemployment in a more comprehensive and pragmatic way. Through profiling unemployment based on the job leavers, job losers and job layoff categories, we can understand patterns of unemployment, as well as the differences in the composition and correlations associated with each form of job loss.

Next, core definitions are presented including a brief review of existing literature. Following that, is a discussion of variables used in this study. The results section includes an evaluation of labor market transition rates and multinomial logit estimates of the likelihood to belong to one of the three categories of unemployment on two levels: comparisons against the control group of job stayers and intergroup pair-wise comparisons. To end is the discussions, future research and limitations section.

\section{DISAGGREGATING THE UNEMPLOYED GROUP: DEFINITIONS}

Some individuals choose to voluntarily enter unemployment, through turnover in the form of a quit or a resignation. For the purpose of this study, the job leavers group is defined as individuals who were employed within the last twelve months, but were not employed at the time of the survey due to voluntary reasons (e.g. quit) (Statistics Canada 2007). Comparatively, the job losers group is defined as individuals who were employed within the last twelve months, but employment was permanently terminated at the time of the survey due to involuntary reasons (e.g. dismissal or permanent layoff) (Statistics Canada 2007). The last group is the job layoff group representing individuals who were temporarily laid off and have a potential for recall (Statistics Canada 2007). It is important to note that the job layoff group experience temporary unemployment with a possibility of recall, whereas job loser's employment is permanently terminated.

As an independent group of unemployed persons, the job leavers group has been studied comprehensively in the past. A number of models propose theoretical antecedents of an employee's intention to leave, including factors such as work and non work-related variables, perceived alternatives, and shock (Porter and Steers 1973; Steers and Mowday 1981; Mobley 1982; Hom and Griffeth 1995; Lee et al. 1996; Carnicer et al. 2004). Hundreds of studies attempt to identify antecedents of voluntary turnover, resulting in many meta-analyses on this topic (Cohen and Cohen 1983; Steel and Ovaille 1984; Cotton and Tuttle 1986; Hom et al. 1992; Tett and Meyer 1993; Hom and Griffeth 1995; Griffeth et al. 2000).

The most recent meta-analysis identified a significant number of variables as direct and indirect predictors of voluntary turnover in the form of quits (Griffeth et al. 2000). Eliminating variables about cognitions and behaviors about the withdrawal process (e.g. intention to quit, job search efforts) individual level variables found to have the highest correlation with voluntary job loss were organizational commitment $(r=-0.27)$, role clarity $(r=-$ $0.24)$, tenure $(r=-0.23)$, role conflict $(r=0.22)$, overall job satisfaction $(r=-0.22)$, and absenteeism $(r=-0.21)$. Additionally, age and marital status were negatively correlated with voluntary turnover $(r=-0.23$ and -0.05 respectively) while education was positively correlated with voluntary turnover $(r=0.06)$ (for all correlations pvalue $<0.05)$. The research ascertained that gender was not significantly correlated with voluntary turnover $(r=$ $0.03)$.

Existing research on turnover generally limits the analysis of the employed versus unemployed groups by treating the job leavers (quit) group as a homogeneous group representing unemployed persons for three main reasons. First, in the past most turnover was voluntary (Byrt 1957; Marsh and Mannari 1977), therefore the study of involuntary turnover may have been perceived as non-imperative. Second, theory was easier to form when turnover could be treated as homogenous. It would be hard to explain quits, dismissals and layoffs in the same theory because they may have different determinants. Focusing on the voluntary turnover category provided a more homogeneous group to research. Third, involuntary turnover is organizationally initiated, so it was assumed that the selection procedure was solely performance based. This lead to the belief that "involuntary exits are desirable because employers would not want to keep poor performers/excess manpower” (Griffeth and Hom 2001: pp 4).

Research on flows into unemployment (i.e., job leavers, job losers and job layoffs) received limited attention in U.S. literature, and remained focused mainly on economic indicators of each category (Borjas 1981; Hamermesh 1989; Farber and Hall 1993; Farber 1997, 1999). These studies had a common sample (series from the Displaced Workers Survey in the 1980's and 1990's) and focused on the antecedents and outcomes of 
unemployment via the job loser and job layoff categories, without consideration of the job leaver category.

Due to a lack of data sources on unemployment in Canada, only Kidd (1994) and Picot et al. (1998) explored the issue of categorizing unemployed persons. Kidd (1994) examined whether a meaningful difference existed between quits and layoffs. The results provided evidence that job leavers and job layoffs were a nonhomogenous group. The study collected Canadian labor market data, including reasons for unemployment in 1986 and 1987. Kidd's econometric model assumed membership into one of four mutually exclusive categories: quit $(\mathrm{n}=617)$, layoff $(\mathrm{n}=261)$, job stayers $(\mathrm{n}=397)$, and a residual (other mover category). The distinction between a quit and a layoff was dependent on whether unemployment was voluntary; assuming that a quit was voluntary and a layoff was involuntary. Based on Kidd's economic perspective, wage equation estimates were developed (controlling for marital status, age, education, industry, occupation and province of residence) and dependent on the nature of the job separation (quit or layoff).

The findings of Kidd's empirical research suggest that when the voluntary versus involuntary distinction is made, the party who wishes to initiate the job separation gains monetary benefits. After job separation, those who quit (voluntarily separated) earned an average salary $18 \%$ higher than job stayers. Likewise, those who were laid off (involuntarily separated) earned an average salary $30 \%$ less than job stayers. This indicated that the economic benefit during an involuntary separation was positive for the employer, since the employee's pay level was not representative of productivity in a fixed market. However, an employee whose market value was higher than the actual wage set by the employer gained the economic benefit of voluntary separation. Therefore, there are opposing antecedents to quits and layoffs. There are a number of limitations of this study. Kidd's study utilized data from the Labor Market Activity Survey (LMAS) of 1986-1987, therefore the data and findings are significantly dated. The sample accessed was full time, male workers, providing only a partial view of unemployment due to limitations in the data collected.

In a second Canadian study, Picot, Lin and Pyper (1998) used a random sample of all Canadian workers to study layoff trends. The information was extracted from the Longitudinal Worker File, which is one component of the Labor Force Survey. Picot et al. (1998) provided evidence of a number of correlations between various factors (such as age, gender, and skill level) and likelihood to experience a layoff. Layoff victims were older (over 55 years of age at time of layoff) when the layoff was a single event. In continuous layoff situations (where the individual was laid off from 5 or more companies within a 10 year span), younger individuals were most likely to be the subjects (between 25 and 34 years of age). Annual earnings, education and skill level were found to be the most influential determinants of the likelihood of experiencing a layoff. However, this study did not include comparisons of layoffs, quits and dismissals.

A crucial finding in the Picot et al. study was that from 1978-1993 a 1\% change in unemployment was associated with a $0.89 \%$ decrease in quit rates, a $0.61 \%$ increase in use of temporary layoffs and a $0.38 \%$ decrease in hiring rates. There was also a small effect on the use of permanent layoffs with a $0.34 \%$ increase in permanent layoffs for every $1 \%$ increase in unemployment. One finding that was evident in the data, but not explicitly stated by the authors is that quit rates and layoff rates consistently reacted in opposite directions. Thus, further support for creating a distinction between job leavers, job losers and job layoffs categories is secured.

Given the exploratory perspective adopted in the research, only a limited number of variables can be used to demonstrate that disaggregating unemployment will enhance our understanding of the unemployment phenomena. The selection of seven variables is rationalized in the next section. Through analysis of these variables, this research aims to secure support for examining unemployment in Canada by disaggregating unemployment using the three categories above.

\section{THEORETICAL PERSPECTIVES IN VARIABLE SELECTION}

Due to the exploratory nature of this research, a limited number of variables were used in our analysis, although additional variables may be influential in characterizing job leavers, losers and layoffs. The variables selected for the data analysis met two minimal standards. One, the variables must have a theoretical link to studies of unemployment. Two, the variables must be measured in the LFS.

Human Capital Theory 
The first two variables are embedded in human capital theory; education and tenure. Human capital refers to an employee's tacit knowledge of firm specific information, such as the knowledge, skills, abilities and other attributes of individual employees (Becker 1963). Firm specific skills such as familiarity with products, procedures and technical characteristics of a firm cannot be transferred among firms (Schultze 1999; Hitt and Ireland 2002).

\section{Education}

Education provides a general training program to help introduce individuals to broad concepts, industries and ideologies. Generally, the higher an individual's education, the less firm specific their skill set; therefore their knowledge and skills are more transferable (Becker, 1963). This also translates into a lower level of firm specific human capital, which can affect organizational decisions regarding employee exits. In Griffeth, Hom and Gaertner's (2000) meta-analysis on antecedents of turnover, a statistically significant positive relationship between education and voluntary turnover (quits) was noted. Although a correlation between education and turnover is established in existing research, no study explicitly examines the relationship between education and different flows into unemployment, as per this study.

Individuals with lower levels of education may be less mobile in the workforce due to their lack of generalizable skills. These individuals may perceive their chances for re-employment to be low, due to high requirements for firm specific training upon reemployment. from a company perspective individuals with low education may not be candidates for layoffs during a downsizing event given that they may have experienced high levels of firm specific knowledge and training.

\section{Tenure}

Tenure refers to the total time an individual is employed by a company (Becker 1963). Generally, the higher an individual's experience with the organization, the more firm specific their skill set (Becker 1963). Traditionally, job tenure provided some protection from layoffs, but the benefits of high tenure are shrinking (Seitchik 1991; Fallick 1996; Farber 1997). Kidd (1995) and Farber (1993) provided evidence that tenure was influential in predicting individual unemployment. Individuals who remain employed had twice as much tenure than those who quit, and individuals who quit generally had slightly longer tenure than layoffs. Tenure groups used in this research align with Kidd's analysis (1994).

In addition to Human Capital factors affecting this variable, longer tenure with a company also suggests that the individual employee may have more invested with the company such as investing in a house near their job, work friendships extending to personal life and an attachment to the job (Chhinzer and Ababneh 2008). These investments are jeopardized when an employee with more experience loses employment. Therefore, we would expect the unemployed groups to have lower tenure regardless of means of unemployment.

\section{Work-related Variables}

The next two variables selected are work-related variables; industry and occupation. Individual workrelated variables include individual job or organizational factors that may be directly related to turnover behavior, such as industry and occupation (Mobley 1982).

Industry

There has been an ongoing debate regarding the influence of industry on turnover. In the United States, chances of layoff increases significantly if the industry an individual is employed in is doing poorly overall (Fallick 1996). Aligned with this perspective, industry differences have a significant and negative correlation with the likelihood for job loss in Canada (Kidd 1994). In contrast, Picot et al. (1998) provided evidence that layoffs are more of an individual company decision, rather than an industry specific decision in Canada. They suggest that companies in the same industry, facing the same economic concerns have multiple options to respond to reduce manpower (e.g. layoff, hiring freeze, technological advancements, reduction of services etc). Therefore, turnover 
cannot be explained by cyclical variations in demand or industry level factors such as growth or decline. This debate remains unresolved; therefore, the inclusion of industry as a variable in this study is justifiable.

Industry trends can be explored using the goods versus services industry difference, as per previous unemployment research. Farber (1993) found that from 1982-1985, job loss in the U.S.A was concentrated in the goods (manufacturing) industry, but in 1986-1991, the job loss was concentrated in the services industry.

Projections for 2009 suggest that the services industry will continue to grow, while growth will stagnate, then decline in primary industries in Canada (Government of Canada and the Ontario Ministry of Training 2007). As good related jobs (manufacturing) become increasingly scarce in the Canadian employment outlook (Statistics Canada 2007), employees may be less likely to quit due to a perceived lack of alternative employment opportunities in this industry. In contrast, employers may be less likely to dismiss employees in the service sector due to a perceived labor shortage in this industry.

\section{Occupation}

The occupation variable may be directly related to flows into unemployment. Over time, the number and types of occupations available to the labor force change due to technological advancements, globalization, economic growth, demographics and consumer behavior (Chhinzer and Ababneh 2008). While there are thousands of possible occupations, we categorized jobs according to the North American Industry Classification System (NAICS). Most users of this type of information create clusters of similar occupations for the use and interpretation of the results (Farber and Hall 1993; Kidd 1994; Fallick 1996; Farber 1997). Similarly, this research uses occupational clusters to analyze the results.

In Ontario, 24\% of job growth between 2004 and 2009 was projected to come from professional jobs while manufacturing was projected to be responsible for an additional 10\% job growth (Government of Canada and the Ontario Ministry of Training 2007). Given that the labor market and perceived alternative employment opportunities differ by occupation, individuals in occupations with expected growth in Canada may be more likely to quit (job leavers). These individuals may perceive that their occupations are in high demand, therefore may choose to exit the firm to gain more desirable employment terms or compensation. Individuals in occupations with minimal growth forecasts may be more likely to be dismissed or laid off (job loser and job layoff), given that these jobs may not be in high demand and may become obsolete. As well, these individuals may be less likely to turnover via quits (job leaver) because of perceptions that the labor market is flooded with qualified candidates, (reducing perceived chances for reemployment). Unemployment trends may vary by occupation, therefore this variable was included in the analysis.

\section{Demographics}

The remaining three variables selected are demographic variables: age, marital status and gender. Demographic variables refer to individual attributes that employees bring to work. These traits remain stable across jobs, employers and contexts, are associated with the individual employee in all settings, and are non-changeable by the employee. Personal characteristics may influence the decision to quit, in that they may help an employee predict their internal versus external labor force advantages and disadvantages (Chhinzer and Ababneh 2008). Also, these demographic conditions can dictate the employee's perception of opportunities outside of the company, as well as likelihood to voluntarily leave.

In contrast, a combination of federal, state and provincial laws has limited management's ability to decide whom to separate from their jobs. Although management should be aware that using demographics as a determinant in practice (dismissals or layoffs) is legal only under exceptional circumstances (e.g. Bona Fide Occupational Requirement), cases of layoffs and dismissals are being met with increased legal resistance (Balkin 1992). As a result, it is possible that the group of job leavers may be demographically different than the job stayers group, but there should be no demographic differences between the job stayers, job losers and job layoffs groups.

\section{METHODS}


Data used in this analysis was collected from the Labor Force Survey (LFS). Started in 1945 and maintained by a body of the Canadian Federal Government (Statistics Canada), the LFS provides the only source of monthly labor force data in Canada. Responses are self-reported, therefore this analysis is one of self-reported measures of flows into unemployment.

Sampling 2\% of the Canadian population a month, the LFS clusters individuals into three main categories: employed, unemployed and not in the labor force. This study uses the group of employed persons (or job stayers) as the base or control group. When the complete sample is assessed, the control group of employed persons overwhelms the unemployed persons group by a ratio of more than 30:1. When the proportion of employed to unemployed (or vice versa) diverges from 50\%, variance and correlations are attenuated (Pedhazur 1982). A correction for this is required. A randomly selected group of employed persons equal in count to the group of unemployed persons allows for true unbiased assessment of correlates and variance of the flows into unemployment (Pedhazur 1982).

Additionally, individuals who are not in the labor force (people unwilling and unable to work) represent a group that is neither employed or unemployed. Therefore, individuals not in the labor force were not included in the analysis. Statistics Canada classifies individuals into one of three unemployed groups: job leavers (quits/resignations), job losers (dismissals/permanent layoff) and job layoffs (temporary layoffs) based on a mix of questions about the unemployment decision and activity prior to unemployment.

Participants in the survey are sampled monthly and form a six month panel. The response rate averages 95\% a month. In the rare case that a participant drops out of the panel, a weight adjustment is applied to the account and the individual is not replaced. The LFS also utilizes a seasonal adjustment for institutional events like vacation, holidays and climate events. Seasonal variations from almost 1,300 participants are adjusted to prevent seasonal factors from effecting employment/unemployment analysis.

Since significant revisions were made to the LFS questionnaire in 1976 and 1997, the period of study is limited to 2000-2004. This ensures reliability of the results, by ensuring consistent survey questions. In order to develop an annual measure of flows into unemployment monthly data was pooled. More specifically, given that survey participants were part of a 6 month panel, we merged information from the March and September data files to create our database. The risk of sampling the same individual in the labor force twice is completely eliminated through forcing six months of difference in the sample, increasing the validity of the results.

A total of 19,273 unique individuals experienced unemployment during the survey period. An equal number of randomly selected employed persons form the control group. Of the unemployed persons group, 3,542 participants experienced temporary layoffs, falling into the job layoff category. An additional 12,397 persons experienced some form of permanent involuntary flow into unemployment (e.g. dismissal or permanent layoff) falling into the job loser category. The remaining 3,334 individuals initiated the flow into unemployment by resigning or quitting, thereby falling into the job leaver category.

\section{RESULTS}

\section{Multinomial Logit Regression Analysis}

Multinomial logit regression (MNL) analysis is conducted here to estimate the probability (or odd ratios) of an individual flowing into the job leaver, job loser, or job layoff category relative to remaining in the job stayer category by using seven predictors (i.e. education, tenure, industry, occupation, age, gender, and marital status). To conduct the MNL analysis, coefficients of a reference group (e.g., job stayer) were set to zero so that the other estimated parameters could be interpreted relative to this reference group.

Using a chi-squared test to evaluate fit $\left(\chi^{2}(54, N=38,546)=12119.754\right)$, the model including seven predictors against the null model (constant-only model) is statistically significant. This means that the model with the seven predictors as a set is outperforming the null model in predicting individual unemployment status. Thus, we 
reject the null hypothesis that all coefficients in our model are jointly zero. The likelihood ratio-test for each of the seven predictors shows that each predictor of our model is statistically significant ( $p$-value $<.001$ ) in influencing the likelihood that an individual will flow into a specific employment status.

Table 1 provides an assessment of the over or under representation of each variable based on the corresponding flow into unemployment, compared to the control group (job stayers). For example, there are $18.7 \%$ more individuals with education levels of 'high school or less' in the job layoff group than in the job stayer group. In contrast, there are $15.1 \%$ less individuals with 'high school or less` education in the job leaver group than in the job stayer group.

Table 1: Labor Market Transition Rates (Percentage Difference in Population as compared to Job Stayers)

\begin{tabular}{|c|c|c|c|}
\hline 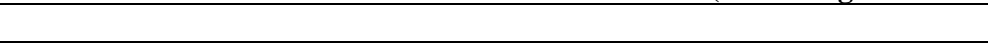 & Job Layoff & Job Loser & Job Leaver \\
\hline \multicolumn{4}{|l|}{ Education } \\
\hline High school or less & $18.7 \%$ & $-1.3 \%$ & $-15.1 \%$ \\
\hline Some post secondary & $-12.3 \%$ & $-4.1 \%$ & $30.1 \%$ \\
\hline Post secondary certificate or diploma & $-5.3 \%$ & $1.7 \%$ & $-1.7 \%$ \\
\hline university and above & $-60.0 \%$ & $2.0 \%$ & $54.0 \%$ \\
\hline \multicolumn{4}{|l|}{ Tenure } \\
\hline 1 year & $-27.8 \%$ & $11.2 \%$ & $-12.2 \%$ \\
\hline 2 years & $-14.8 \%$ & $-2.6 \%$ & $26.1 \%$ \\
\hline $3-4$ years & $8.9 \%$ & $-8.9 \%$ & $25.0 \%$ \\
\hline $5-9$ years & $38.7 \%$ & $-13.5 \%$ & $12.6 \%$ \\
\hline 10 years + & $75.7 \%$ & $-19.3 \%$ & $-8.6 \%$ \\
\hline \multicolumn{4}{|l|}{ Occupation } \\
\hline Management, Business, Finance, and Administrative Occupations & $-50.0 \%$ & $3.1 \%$ & $43.8 \%$ \\
\hline Sales and Service Occupations & $-33.2 \%$ & $-4.5 \%$ & $51.5 \%$ \\
\hline Trades, Transportation and Equipment Operators and Related Occupations & $36.3 \%$ & $0.3 \%$ & $-39.7 \%$ \\
\hline Occupations Unique to Primary Industries, Processing and Manufacturing & $44.7 \%$ & $0.5 \%$ & $-22.8 \%$ \\
\hline Other & $-46.7 \%$ & $2.5 \%$ & $38.5 \%$ \\
\hline \multicolumn{4}{|l|}{ Industry } \\
\hline Goods & $38.5 \%$ & $0.7 \%$ & $-48.4 \%$ \\
\hline Services & $-32.1 \%$ & $-0.6 \%$ & $40.4 \%$ \\
\hline \multicolumn{4}{|l|}{ Sex } \\
\hline Male & $7.8 \%$ & $2.3 \%$ & $-17.1 \%$ \\
\hline Female & $-12.6 \%$ & $-3.7 \%$ & $27.8 \%$ \\
\hline \multicolumn{4}{|l|}{ Age } \\
\hline $25-34$ & $-15.0 \%$ & $-1.8 \%$ & $22.9 \%$ \\
\hline $35-44$ & $2.1 \%$ & $0.0 \%$ & $-2.1 \%$ \\
\hline $45-54$ & $6.4 \%$ & $0.8 \%$ & $-10.5 \%$ \\
\hline $55-64$ & $15.3 \%$ & $2.5 \%$ & $-24.6 \%$ \\
\hline \multicolumn{4}{|l|}{ Marital status } \\
\hline Married & $44.8 \%$ & $28.9 \%$ & $24.8 \%$ \\
\hline Single & $-56.7 \%$ & $-39.5 \%$ & $-37.6 \%$ \\
\hline Divorced/Widowed/Separated & $-14.3 \%$ & $6.7 \%$ & $14.3 \%$ \\
\hline
\end{tabular}

The results in Table 1 imply that job losers (dismissals) and job stayers are similar in proportion of educational experience, suggesting that education level is not a main variable in the decision function to dismiss an employee. In fact, job stayers and job losers groups are consistently similar in representation, with the exception of tenure and marital status.

There is a negative relationship between education level and likelihood to experience a temporary layoff. Specifically, employees with high school or less education represent $18.7 \%$ more of the job layoff group than the job stayer group. Comparatively, employees with university and above education represent almost $60 \%$ less of those experiencing a job layoff than their proportion in the remaining labor force. This provides empirical support that education levels provide protection from layoff, as theorized in human capital theory.

Flow into unemployment is more likely to be employee initiated when an employee possessed higher levels 
of education. Specifically, employees with high levels of education represent $54 \%$ more of the job leaver category than they represent in the labor force. Aligned with this, individuals with lower levels of education were $15 \%$ less likely to initiate job loss. Following human capital theory, those with transferable skill sets (gained from general training and education) are more prone to initiate job loss through participation in the job leaver category than the job stayers and those with lower levels of education.

At first glance, the results of tenure do not clearly identify a relationship between experience with the firm and flows into unemployment. However, when year 1 is eliminated, the relationships become more consistent. Employees with high tenure make up more than their fair share of the employees laid off; almost doubling their representation in the 10 years plus group, as compared to the control group of job stayers. As tenure increases, so does the representation in the group of laid off persons. The opposite situation exists for the job leavers group. As tenure increases, representation in the job leavers group decreases. In contrast to patterns between job losers and job stayers outlined in the education variable, tenure appears to negatively influence likelihood to be dismissed. Employees in their first year of employment are less likely to quit or be laid off, but slightly more likely to be dismissed, which is the opposite of the results for the remaining years.

Tenure can also be viewed as a unique variable in that the group of job losers is somewhat affected by tenure when compared to job stayers. With the exception of tenure and marital status, the group of job losers was not proportionately different than the control group. The results suggest that dismissals and permanent layoff likelihood decreases with tenure. In the first year, employees are most likely to fall into the job losers category (represented $11.2 \%$ more in the job losers group than the job stayers group), and tenure does provide protection from dismissals and permanent layoffs in later years, when compared to the job stayers group (represented $19.3 \%$ less in the job losers group than the job stayers group).

Management and business related occupations showed the largest range of change based on unemployment category. Individuals with these occupations are underrepresented in the job layoff group (by 50.0\%), but overrepresented in the job leaver group (by $43.8 \%$ ) when compared to their portion of the job stayers group. A similar pattern is revealed with sales and service jobs. The opposite situation holds true for trades, primary industries and manufacturing in Canada. Therefore, individuals in white collar jobs are significantly more likely to initiate job loss via quitting or resigning from their job, while those in traditional blue collar jobs are much more likely to experience a layoff in Canada.

A similar pattern is formed when we contrast the goods industry with the services industry. Individuals in the goods industry are significantly more likely to experience a job layoff, while less likely to voluntarily leave their job. The opposite relationship is found in the services industries. As hypothesized, perhaps the growth of the services industries and the perceived tightness in the services labor market is responsible for these differences. The results suggest that when the services versus manufacturing differentiation is made, trends of flows into unemployment significantly change. Thus, this variable is valuable in differentiating unemployment in Canada.

Females are disproportionately overrepresented in the job leaver category (by 27.8\%) and underrepresented in the job layoff category (by 12.8\%). There may be a number of factors associated with this such as age, non workrelated responsibilities, occupation and industry differences that can be attributed to gender. Future studies may be valuable in explaining the differences highlighted in the results for unemployment trends based on gender in Canada, as per Table 1.

The age variable identifies an interesting trend. While the job losers group is almost identical in terms of representation to the job stayers group, as age increases, the chances of unemployment through job layoffs increases and unemployment through voluntary job loss (job leavers) decreases. This suggests a positive relationship between age and likelihood to be laid off, and a negative relationship between age and likelihood to quit or resign. This variable is important in that if the results were aggregated (comparing employed versus unemployed persons) no effect of age would be evident. However, when the age category is disaggregated, it is highly influential in determining types of unemployment in Canada.

Table 2: Multinomial Logit Estimates of the Likelihood of Flows into Unemployment 


\begin{tabular}{|c|c|c|c|c|}
\hline & $\begin{array}{l}\text { Job Layoff } \\
\text { Vs. Stayers }\end{array}$ & $\begin{array}{l}\text { Job Loser } \\
\text { Vs. Stayers }\end{array}$ & $\begin{array}{l}\text { Job Leaver } \\
\text { Vs. Stayers }\end{array}$ & $\begin{array}{l}\text { All movers } \\
\text { Vs. Stayers }\end{array}$ \\
\hline \multicolumn{5}{|l|}{ Education } \\
\hline high school or less & $\begin{array}{c}1.145^{* * *} \\
(3.142)\end{array}$ & $\begin{array}{c}0.494 * * * \\
(1.639)\end{array}$ & $\begin{array}{c}0.246^{* * *} \\
(1.280)\end{array}$ & $\begin{array}{l}0.512 * * \\
(1.668)\end{array}$ \\
\hline some post secondary & $\begin{array}{l}0.782 * * * \\
(2.186)\end{array}$ & $\begin{array}{c}0.259 * * * \\
(1.296)\end{array}$ & $\begin{array}{c}0.285^{* *} * \\
(1.329)\end{array}$ & $\begin{array}{l}0.309 * * \\
(1.362)\end{array}$ \\
\hline post secondary certificate or diploma & $\begin{array}{c}0.802 * * * \\
(2.230)\end{array}$ & $\begin{array}{c}0 . .298 * * * \\
(1.347)\end{array}$ & $\begin{array}{c}0.057 \\
(1.059)\end{array}$ & $\begin{array}{l}.284 * * \\
(1.328)\end{array}$ \\
\hline \multicolumn{5}{|l|}{ Tenure } \\
\hline 1 year & $\begin{array}{l}1.376 * * * \\
(3.956)\end{array}$ & $\begin{array}{l}2.626 * * * \\
(13.820)\end{array}$ & $\begin{array}{l}2.078 * * * \\
(7.992)\end{array}$ & $\begin{array}{l}2.279 * * \\
(9.768)\end{array}$ \\
\hline 2 years & $\begin{array}{c}0.834 * * \\
(2.303)\end{array}$ & $\begin{array}{c}1.664 * * * \\
(5.280)\end{array}$ & $\begin{array}{c}1.508 * * * \\
(4.516)\end{array}$ & $\begin{array}{l}1.454 * * \\
(4.280)\end{array}$ \\
\hline $3-4$ years & $\begin{array}{c}0.771 * * * \\
(2.162)\end{array}$ & $\begin{array}{l}1.294 * * * \\
(3.647)\end{array}$ & $\begin{array}{c}1.235 * * * \\
(3.438)\end{array}$ & $\begin{array}{l}1.153^{* *} \\
(3.167)\end{array}$ \\
\hline $5-9$ years & $\begin{array}{c}0.391 * * * \\
(1.478)\end{array}$ & $\begin{array}{c}0.664 * * * \\
(1.942)\end{array}$ & $\begin{array}{c}0.624 * * * \\
(1.865)\end{array}$ & $\begin{array}{r}0.577 * * \\
(1.781) \\
\end{array}$ \\
\hline \multicolumn{5}{|l|}{ Occupation } \\
\hline $\begin{array}{l}\text { Occupations Unique to Primary Industry, } \\
\text { Processing, Manufacturing }\end{array}$ & $\begin{array}{l}1.440 * * * \\
(4.222)\end{array}$ & $\begin{array}{l}0.449 * * * \\
(1.568)\end{array}$ & $\begin{array}{c}0.083 \\
(1.086)\end{array}$ & $\begin{array}{l}0.581 * * \\
(1.789)\end{array}$ \\
\hline Sales and Service Occupations & $\begin{array}{c}0.680 * * * \\
(1.975)\end{array}$ & $\begin{array}{r}0.128 * * \\
(1.136)\end{array}$ & $\begin{array}{c}0.261 * * * \\
(1.299)\end{array}$ & $\begin{array}{c}0.243 * * \\
(1.275)\end{array}$ \\
\hline Trades, Transportation and Equipment & $1.696^{* * *}$ & $0.526 * * *$ & $0.148^{*}$ & $0.682 * *$ \\
\hline Operators and Related Occupations & $(5.454)$ & $(1.691)$ & $(1.160)$ & $(1.977)$ \\
\hline Others & $\begin{array}{l}.244 * * \\
(1.276) \\
\end{array}$ & $\begin{array}{r}-0.069 \\
(.933) \\
\end{array}$ & $\begin{array}{c}-0.193 * * \\
(.824)\end{array}$ & $\begin{array}{l}-.052 \\
(.949)\end{array}$ \\
\hline \multicolumn{5}{|l|}{ Industry } \\
\hline Goods & $\begin{array}{c}0.804 * * * \\
(2.234)\end{array}$ & $\begin{array}{c}0.478 * * * \\
(1.613)\end{array}$ & $\begin{array}{c}-0.215^{* *} \\
(0.807) \\
\end{array}$ & $\begin{array}{c}0.436 * * \\
(1.547)\end{array}$ \\
\hline \multicolumn{5}{|l|}{ Sex } \\
\hline Male & $\begin{array}{c}-0.270 * * * \\
(0.764) \\
\end{array}$ & $\begin{array}{c}0.098 * * \\
(1.103)\end{array}$ & $\begin{array}{l}-0.013 \\
(0.987) \\
\end{array}$ & $\begin{array}{c}0.007 \\
(1.007) \\
\end{array}$ \\
\hline \multicolumn{5}{|l|}{ Age } \\
\hline $25-34$ & $\begin{array}{l}-0.403 * * * \\
(0.668)\end{array}$ & $\begin{array}{c}-0.549 * * * \\
(0.577)\end{array}$ & $\begin{array}{c}0.017 \\
(1.017)\end{array}$ & $\begin{array}{c}-0.407 * * \\
(.666)\end{array}$ \\
\hline $35-44$ & $\begin{array}{c}-0.213 * * \\
(0.809)\end{array}$ & $\begin{array}{c}-0.306 * * * \\
(0.736)\end{array}$ & $\begin{array}{c}0.010 \\
(1.010)\end{array}$ & $\begin{array}{c}-0.232 * * \\
(.793)\end{array}$ \\
\hline $45-54$ & $\begin{array}{c}-0.137 * \\
(0.872) \\
\end{array}$ & $\begin{array}{c}-0.165^{* * *} \\
(0.848) \\
\end{array}$ & $\begin{array}{c}0.024 \\
(1.024) \\
\end{array}$ & $\begin{array}{c}-0.127 * \\
(.881) \\
\end{array}$ \\
\hline \multicolumn{5}{|l|}{ Marital status } \\
\hline Single & $\begin{array}{l}0.109^{*} \\
(1.115)\end{array}$ & $\begin{array}{l}0.420 * * * \\
1.522\end{array}$ & $\begin{array}{l}0.478^{* *} \\
(1.613)\end{array}$ & $\begin{array}{l}0.375 * * \\
(1.455)\end{array}$ \\
\hline Others & $\begin{array}{c}0.203 * * * \\
(1.225)\end{array}$ & $\begin{array}{c}0.369 * * * \\
(1.447)\end{array}$ & $\begin{array}{c}0.448 \\
(1.565)\end{array}$ & $\begin{array}{c}0.349 \\
(1.418)\end{array}$ \\
\hline
\end{tabular}

The reference variables are: job stayer (employment status), university and above (education), 10+ years (tenure), Management, Business, Finance, and Administrative (occupation), services (industry), female (sex), 55-64 (age), and married (marital status). The coefficients for the reference groups are all zero.

Values in parenthesis indicate the odds ratio (indicate the magnitude of the likelihood of belonging to a certain flow into unemployment relative to a control group of job stayers)

$* * * \mathrm{p}<0.001, * * \mathrm{p}<0.01, * \mathrm{p}<0.05$ (two tailed test)

Married individuals are overrepresented (24.8 to $44.8 \%)$, while singles are significantly underrepresented (37.6 to 56.7\%) in all categories of unemployment. This is one of two variables in which the job loser category is significantly different than the job stayers category. As well, individuals who were in a partnership that no longer exists due to death, divorce or separation are $14.3 \%$ overrepresented in the job leaver category, and $14.3 \%$ underrepresented in the job layoff category. This example further supports disaggregation of unemployment data in Canada. The relationship between marital status and unemployment remains largely unexplored in research, but the 
results suggest a direct or indirect influence of marital status on quits, dismissals, permanent layoffs and temporary layoffs in the Canadian labor force.

Table 2 presents more related information concerning the multinomial logit analysis (MNL). The first, second, and third columns of Table 2 report the coefficient estimates and the odds ratios (reported in parentheses) of our multinomial logit analysis. The first column presents the coefficient estimates and the odd ratios comparing job layoffs with job stayers. The second column presents the coefficient estimates and the odd ratios comparing job losers with job stayers. The third column presents the coefficient estimates and the odd ratios comparing job leavers with job stayers. A positive coefficient indicates that a specific category of an independent variable increases the likelihood of being in a certain work status in comparison to the job stayers group (the reference group), while a negative coefficient indicates that a specific category (corresponding category or variable) of an independent variable decreases the likelihood of being in a certain work status in comparison to the job stayers group (the reference group). The fourth column reflects the odds ratios when all movers are aggregated (those who lost jobs) and this value is compared against the aggregate job stayers category.

Asterisks identify the categories of the independent variables that have significant effects on the flows into unemployment based on our three categories. The probability (odds) ratios indicate the magnitude of the likelihood of belonging to a certain flow into unemployment relative to the job stayers group. A variable that increases the likelihood of being in a specific unemployed group relative to the job stayers group has probability ratio greater than one, while a variable that decreases the likelihood of being in a specific work status has a probability ratio lower than one. Following is a presentation for the effects of each of the seven variables on the flows into unemployment.

\section{Education}

Comparing job layoff with job stayer groups, column 1 of Table 2 shows that the coefficient for the categories 'high school or less', 'some post secondary', and 'post secondary certificate or diploma' are positive and significant. Individuals with 'high school or less', 'some post secondary', and 'post secondary certificate or diploma' levels of education are more likely than individuals with 'university and above' education (reference group) to experience temporary layoffs. Specifically, Table 2 shows that the probability of being in a job layoff status relative to the probability of being in a job stayer status is higher for individuals who hold 'high school or less' (3.14 times higher), 'some post secondary' (2.19 times higher), and 'post secondary certificate or diploma' (2.23 times higher) than for individuals who hold 'university and above' degree. Comparing the job loser group with job stayers, column 2 of Table 2 reports similar effects for the education categories as those reported above when comparing job layoff with job stayers, but with different odds ratio. Comparing job leavers with job stayer, column 3 of Table 2 also reports similar results as those discussed above except that individuals who hold "post secondary certificate or diploma' were not significant.

\section{Tenure}

With regard to tenure, the results demonstrate that the coefficient for individuals who have been with the organization for ' 1 year', ' 2 years', ' 3 years' and ' $5-9$ years' are more likely to be in job layoff, job loser, or job leaver category than to be in the job stayers category, as compared to those who have been with the organization for ten years and above (i.e., the reference group for tenure). For example, individuals who have been with the organization for two years are 13.82 times more likely to flow into job losers' status than individuals who have been with the organization for ten years or more. The results also indicate that the likelihood of flowing into job loser, layoff, or leaver status diminishes as individuals gain more tenure with an organization. For example, the odds ratios of flow into job layoff status are highest, in descending order, for: (a) individuals who have one year tenure (3.96); (b) individuals who have two years (2.30), (c) individuals who have three to four years (2.16) and individuals who have five to nine years of tenure (1.48).

\section{Occupation}

The result from Table 2 show that the probabilities of a job layoff relative to the probability of a job stayers status is higher for individuals who worked for 'trades, transportation and related occupations', 'primary industry and manufacturing', 'sales and service occupations', and the other occupations category (in that order) than for 
individuals in the reference group (i.e. the category 'management and administrative related'). This means that individuals who hold occupations in management and administrative related were less likely to be laid off than individuals who are holding all the other type of occupations. Similar results are observed when comparing the probability for those of job losers to those of job stayers, however with different odd ratios.

Industry

Individuals who worked in the goods industry were significantly more likely to flow into job layoffs or job losers category than to remain in job stayers category, as compared to those in the service industry. However, individuals who worked in the goods industry are significantly less likely to flow into job leaver category than to remain in job stayers category, as compared to those in the service industry.

\section{Gender}

Comparing flows into job layoffs with flows into job stayers, the coefficient for "Male" is negative and significantly different from zero. This indicates that males are less likely than females to flow into the job layoff category. Comparing flows into job losers with flows into job stayers, the result also shows that males are less likely than females to flow into job layoffs category. However, although the above findings concerning gender are significant, their magnitudes are relatively small.

Age

According to the results in Table 2, age is also an important factor in determining the flows into unemployment. All the coefficients that comparing job layoffs and job losers with job stayers for the different levels of the age categories (i.e. 25-34,35-44, and 45-54) are negative and significantly different from the reference group (i.e. 55-64 age group). The interpretation of this is that younger workers are less likely to flow into the job layoff or job loser categories relative to job stayers. When compared the flows into job leavers relative to job stayers, we observed no significant effect for age.

\section{Marital Status}

Although the results in Table 2 show significant relationships between the sub-categories of the marital status variable and the flows into unemployment, the magnitudes of flowing into a specific work status are very minimal.

\section{Univariate Logit Analysis}

Existing research examining job separation does not differentiate among the different types unemployment (Borjas 1981; Kidd 1994). Specifically, past research grouped all the job movers into one category, which they labeled as job movers. However this research posits that there are different categories of unemployment and these categories are uniquely influenced by the seven predictors suggested in this study. To support our argument, we conducted an univariate logit analysis and compare its results with the multinomial analysis results discussed above.

Column 4 of Table 2 provides the binary logit analysis results. Although the result of the binary analysis demonstrates that the seven factors significantly influenced the probability (odd ratios) of an individual being classified into job stayer or job mover work status, a multinomial logit analysis that disaggregates job movers into three categories (job layoffs, job losers, and job leavers) demonstrates that there are significant differences in the effect of the factors associated with these categories. For example, the results clearly demonstrate that the odds ratios of flowing into job layoff, job loser, or job leaver category, compared with the flows into a job stayers category, are respectively, 3.14, 1.63, and 1.28 times higher for individuals who have high school or less level of education. In addition, table 2 also shows that the odds of flowing into job layoff, job loser, or job leaver category, compared with the flows into a job stayers category, are respectively, 3.95, 13.82, and 7.99 times higher for individuals who worked with an organization for a year or less.

Table 3: Multinomial Logit Estimates of the Likelihood of Flows into Unemployment 


\begin{tabular}{|c|c|c|c|}
\hline & $\begin{array}{c}\text { Job losers } \\
\text { Vs. } \\
\text { leavers } \\
\end{array}$ & $\begin{array}{c}\text { Job layoffs } \\
\text { Vs. } \\
\text { leavers } \\
\end{array}$ & $\begin{array}{c}\text { Job layoffs } \\
\text { Vs. } \\
\text { losers } \\
\end{array}$ \\
\hline \multicolumn{4}{|l|}{ Education } \\
\hline high school or less & $\begin{array}{c}0.248 * * \\
(1.281)\end{array}$ & $\begin{array}{c}0.898 * * \\
(2.456)\end{array}$ & $\begin{array}{c}0.651 * * \\
(1.917)\end{array}$ \\
\hline some post secondary & $\begin{array}{r}-0.025 \\
(.975)\end{array}$ & $\begin{array}{c}0.498 * * \\
(1.645)\end{array}$ & $\begin{array}{c}0.523 * * \\
(1.687)\end{array}$ \\
\hline post secondary certificate or diploma & $\begin{array}{c}0.241 * * \\
(1.272)\end{array}$ & $\begin{array}{c}0.744 * * \\
(2.105)\end{array}$ & $\begin{array}{c}0.504 * * \\
(1.655)\end{array}$ \\
\hline \multicolumn{4}{|l|}{ Tenure } \\
\hline 1 year & $\begin{array}{l}.548 * * \\
(1.729)\end{array}$ & $\begin{array}{c}-.702 * * \\
(.495)\end{array}$ & $\begin{array}{c}-1.250 * * \\
(.286)\end{array}$ \\
\hline 2 years & $\begin{array}{c}.156^{*} \\
(1.169)\end{array}$ & $\begin{array}{c}-0.673 * * \\
(.510)\end{array}$ & $\begin{array}{c}-0.830 * * \\
(.436)\end{array}$ \\
\hline 3-4 years & $\begin{array}{c}.059 \\
(1.061)\end{array}$ & $\begin{array}{c}-.464 * * \\
(.629)\end{array}$ & $\begin{array}{c}-.523 * * \\
(.593)\end{array}$ \\
\hline $5-9$ years & $\begin{array}{c}0.040 \\
(1.041) \\
\end{array}$ & $\begin{array}{c}-0.233 @ \\
(.792) \\
\end{array}$ & $\begin{array}{c}-0.273 * * \\
(.761) \\
\end{array}$ \\
\hline \multicolumn{4}{|l|}{ Occupation } \\
\hline Management, Business, Finance, and Administrative Occupations & $\begin{array}{l}-.124 \\
(.884)\end{array}$ & $\begin{array}{c}-0.437 * * \\
(.646)\end{array}$ & $\begin{array}{c}-0.313^{*} \\
(.731)\end{array}$ \\
\hline Sales and Service Occupations & $\begin{array}{c}-0.257 * * \\
(.773)\end{array}$ & $\begin{array}{r}-0.018 \\
(.983)\end{array}$ & $\begin{array}{l}0.240^{*} \\
(1.271)\end{array}$ \\
\hline Trades, Transportation and Equipment Operators and Related Occupations & $\begin{array}{l}0.254^{*} \\
(1.289)\end{array}$ & $\begin{array}{l}1.111^{* *} \\
(3.038)\end{array}$ & $\begin{array}{l}0.858 * * \\
(2.358)\end{array}$ \\
\hline Occupations Unique to Primary Industries, Processing and Manufacturing & $\begin{array}{l}0.243^{*} \\
(1.275)\end{array}$ & $\begin{array}{l}0.921 * * \\
(2.512)\end{array}$ & $\begin{array}{l}0.678 * * \\
(1.969)\end{array}$ \\
\hline \multicolumn{4}{|l|}{ Industry } \\
\hline Goods & $\begin{array}{l}0.693 * * \\
(1.999)\end{array}$ & $\begin{array}{l}1.019 * * \\
(2.769)\end{array}$ & $\begin{array}{l}0.326 * * \\
(1.385)\end{array}$ \\
\hline \multicolumn{4}{|l|}{ Sex } \\
\hline Male & $\begin{array}{l}0.111 * \\
(1.117) \\
\end{array}$ & $\begin{array}{c}-0.257 * * \\
(.744) \\
\end{array}$ & $\begin{array}{c}-0.368 * * \\
(.692) \\
\end{array}$ \\
\hline \multicolumn{4}{|l|}{ Age } \\
\hline $25-34$ & $\begin{array}{c}-0.566^{* *} \\
(.568)\end{array}$ & $\begin{array}{c}-0.420 * * \\
(.657)\end{array}$ & $\begin{array}{l}0.146 * \\
(1.157)\end{array}$ \\
\hline $35-44$ & $\begin{array}{c}-0.316^{* *} \\
(.729)\end{array}$ & $\begin{array}{c}-0.222 @ \\
(.801)\end{array}$ & $\begin{array}{c}0.094 \\
(1.098)\end{array}$ \\
\hline $45-54$ & $\begin{array}{c}-0.188^{*} \\
(.828) \\
\end{array}$ & $\begin{array}{l}-0.160 \\
(.852) \\
\end{array}$ & $\begin{array}{c}0.028 \\
(1.028) \\
\end{array}$ \\
\hline \multicolumn{4}{|l|}{ Marital status } \\
\hline Married & $\begin{array}{c}-0.058 * * \\
(1.059)\end{array}$ & $\begin{array}{c}0.369 * * \\
(1.446)\end{array}$ & $\begin{array}{c}0.311^{* *} \\
(1365)\end{array}$ \\
\hline Single & $\begin{array}{l}-0.021 \\
(0.979)\end{array}$ & $\begin{array}{c}0.124 \\
(1.446)\end{array}$ & $\begin{array}{c}0.145 @ \\
(.1156)\end{array}$ \\
\hline
\end{tabular}

Reference variables are: university and above (education), 10+ years (tenure), other (occupation), services (industry), female (sex), 55-64 (age), divorced, widowed or separated (marital status)

Values in parenthesis indicate the odds ratio (indicate the magnitude of the likelihood of belonging to a certain flow into unemployment relative to the indicated group)

$* * * \mathrm{p}<0.001, * * \mathrm{p}<0.01, * \mathrm{p}<0.05$ (two tailed test)

To examine if these ratios are significantly different from each other, two more new separate multinomial logit analyses were conducted using the job leavers as the reference group for the first analysis and using job losers as the reference group for the second analysis. Table 3 shows the result of these multinomial logit analyses. For example, table 3 shows that individuals who have high school or less are more likely to experience dismissal or permanent layoff (odd ratio $=1.28$ ) and temporary layoff (odd ratio $=2.46$ ) than voluntarily enter unemployment 
through resigning. Table 3 also provides several significant results that demonstrate that there are different types of movers (or flows into unemployment) and these types are differently influenced by the seven predictors suggested in this study. In sum, the above discussed analysis provide strong support for our arguments regarding the need of disaggregating job movers into three categories (job layoffs, job losers, and job leavers) instead of pooling them into one group.

\section{CONCLUSION AND DISCUSSION}

There are a number of noteworthy contributions of this paper. Overall, this research is just the beginning of our understanding patterns of flows into unemployment at both practical and theoretical levels. The unemployed group can no longer be assumed to be homogeneous. There are significant differences in the composition and correlations associated with the job layoff, job leaver and job loser groups. Table 2 clearly identifies that disaggregating the unemployed group helps us understand the patterns of flows into unemployment in a more comprehensive and pragmatic way.

As outlined in Table 1, the job loser group is not significantly different than the job stayer group. These two groups are different only in the marital status and tenure of their members. This suggests that when dismissing an employee, age, gender, education, occupation and industry do not change the composition of the active labor force. Instead, the composition of the active labor force is significantly affected by job layoffs and job leavers. It is critical to note that on average, if the job layoff group was over represented in a specific category, then the opposite relationship is found for the job leaver group (e.g. there were 48.4\% less people in the job leaver group and 38.5\% more people in the job layoff group than in the job stayer group for the goods industry) and vice versa. Future research can evaluate if there are consistently opposite antecedents to job layoff and job leaver groups.

Patterns of unemployment have been outlined in this paper. For example, the higher the education, the lower the likelihood to be laid off. Additionally, individuals employed in the services industry are predominantly more likely to quit (job leaver), whereas individuals employed in the manufacturing industry are more likely to be laid off (job layoff). These patterns can be further solidified in future research to address why these norms are occurring and what the practical implications of these differences are.

The multinomial data analysis can be arranged into an algorithm to help predict patterns of labor force movement as the mix of the labor force changes. This data can be used for multiple purposes such as policy development for unemployment insurance, human resources planning within the firm, and even career selection. The sample provides statistical strength and the data spans across a five year period, securing our confidence in the generalizability of the results.

Limitations of this study include the restricted number of variables used in this research. Due to the exploratory nature of the research, only seven variables were analysed to suggest differences in categories of unemployed persons. Future studies can include behavior or cognitive variables (organizational commitment, job satisfaction, work-related stress), economic variables (wages, inflation) and additional demographic variables (race, visible minority status, number of dependants). As well, the data is limited to the Canadian labor force and crosssectional in nature. The diversity of the labor force and the complexity of understanding employment patterns can be evaluated using similar studies across countries, or in a longitudinal analysis.

\section{AUTHOR INFORMATION}

Dr. Nita N. Chhinzer is an Assistant Professor of Human Resources at the Department of Business, University of Guelph. Her research is concentrated on Strategic Human Resources Management, with a strong focus on downsizing practices, procedures and ethics. Her program of research includes securing a stronger understanding of downsizing activity in the Canadian context, with an aim to effect public policy and legislation regarding layoffs. She has gained international recognition with conference participation including Athens, Greece, Paris, France, and many North American speaking engagements. She secured her PhD from the Faculty of Business at McMaster University. 
Dr. Khaldoun Ababneh is an Assistant Professor of Management at the American University of Dubai. His research is concentrated attribution, fairness, recruitment, selection, and employee motivation. He secured his $\mathrm{PhD}$ from the Faculty of Business at McMaster University.

\section{REFERENCES}

1. Aaronson, S., Fallick, B., Figura, A., and Pingle, J. (2006). The recent decline in the labor force participation rate and its implications for potential labor supply/comments and discussion. Brookings Papers on Economic Activity, 69-145.

2. Autor, D. H., Katz, L. F., and Kearney, M. S. (2006). The polarization of the U.S. labor market. The American Economic Review, 96(2), 189.

3. Balkin, D. B. (1992). Managing employee separations with the reward system. The Executive, 6(4), 64.

4. Becker, G. (1963). Human capital. New York: Columbia Press.

5. Borjas, G. J. (1981). Job mobility and earnings over the life cycle. Industrial and Labor Relations Review, 34(3), 365.

6. $\quad$ Byrt, W. (1957). Methods of measuring labor turnover. Personnel Practices Bulletin, 13, 413-417.

7. Canada, S. (2007). Guide to the labour force survey. In L. S. Division (Ed.): Minister of Industry.

8. Cappelli, P. (2005). Will there really be a labor shortage? Human Resource Management, 44(2), 143-150.

9. Carnicer, M., Sanchez, A., Perez, M., and Jimenez, M. (2004). Analysis of internal and external labor mobility: A model of job-related and non-related factors. Personnel Review, 33(2), 222.

10. Chhinzer, N. and Ababneh, K. I. (2008). Disaggregating Unemployment: Job Leavers, Losers and Layoffs, Human Resources Division. in Proceedings of Administrative Sciences Academy of Canada Annual Conference, Halifax, NS, Canada.

11. Cohen, J., and Cohen, P. (1983). Applied multiple regression correlation analysis for the behavior sciences (2nd ed). Hillsdale, NJ: Erlbaum.

12. Cotton, J., and Tuttle, J. (1986). Employee turnover: A meta- analysis and review with implications for research. Academy of Management Review, 11, 55-70.

13. Fallick, B. C. (1996). A review of the recent empirical literature on displaced workers. Industrial and Labor Relations Review, 50(1), 5.

14. Farber, H. S. (1997). The changing face of job loss in the united states, 1981-1995. Brookings Papers on Economic Activity.

15. Farber, H. S. (1999). Mobility and stability: The dynamics of job change in labor markets. The Handbook of Labor Economics, 3.

16. Farber, H. S., and Hall, R. (1993). The incidence and costs of job loss: 1982-91; comments and discussion. Brookings Papers on Economic Activity (1), 73.

17. Government of Canada and the Ontario Ministry of Training, C. a. U. (2007). Ontario job futures. Labour Market Information and Research group of the Ministry of Training, Ontario Regional Office (Ed.): Ontario Ministry of Training, Colleges and Universities and the Government of Canada.

18. Griffeth, R., and Hom, P. (2001). Retaining valued employees. Thousand Oaks: Sage Publications.

19. Griffeth, R. W., Hom, P. W., and Gaertner, S. (2000). A meta-analysis of antecedents and correlates of employee turnover: Update, moderator tests, and research implications for the next millennium. Journal of Management, 26(3), 463.

20. Hamermesh, D. S. (1989). What do we know about worker displacement in the U.S.? Industrial Relations, 28(1), 51.

21. Hanisch, K. (1999). Job loss and unemployment research from 1994-1998: A review and recommendations for research and intervention. Journal of Vocational Behavior, 55, 188-220.

22. Hitt, M., and Ireland, D. (2002). The essence of strategic leadership: Managing human and social capital. Journal of Leadership and Organizational Studies, 9(1), 3.

23. Hom, P., Caranikas-Walker, F., Prussia, G. E., and Griffeth, R. (1992). A meta-analytical structural equation model of employee turnover. Journal of Applied Psychology, 77, 890-909.

24. Hom, P. W., and Griffeth, R. (1995). Employee turnover. Cincinnati, OH: South-Western.

25. Juhn, C., and Potter, S. (2006). Changes in labor force participation in the United States. The Journal of Economic Perspectives, 20(3), 1.

26. Kidd, M. P. (1991). An econometrc model of interfirm labor mobility. Econometrica, 24, 517-535. 
27. Kidd, M. P. (1994). Some Canadian evidence on the quit/lay-off distinction. The Canadian Journal of Economics, 27(3), 709.

28. Lee, T. L., Mitchell, T. R., Wise, L., and Fireman, S. (1996). An unfolding model of voluntary employee turnover. Academy of Management Journal, 39(1), 5.

29. Marsh, R. M., and Mannari, H. (1977). Organizational commitment and turnover - a prediction study. Administrative Science Quarterly, 22(1), 57.

30. McLaughlin, K. (1991). A theory on quits and layoffs with efficient turnover. Journal of Political Economy, 99(1-29).

31. Mobley, W. (1982). Employee turnover: Causes, consequences and control. Reading: Addison-Wesley.

32. Panagiotidis, T., and Pelloni, G. (2007). Nonlinearity in the Canadian and U.S. Labor markets: Univariate and multivariate evidence from a battery of tests. Macroeconomic Dynamics, 11(5), 613.

33. Pedhazur, E. J. (1982). Multiple regression in behavioral research: Explanation and prediction (2nd ed.). New York: Holt, Rinehart and Winston.

34. Picot, G., Lin, Z., and Pyper, W. (1998). Permanent layoffs in Canada: Overview and longitudinal analysis. The Canadian Journal of Economics, 31(5), 1154.

35. Porter, L. W., and Steers, R. M. (1973). Organizational, work and personal factors in employee turnover and absenteeism. Psychological Bulletin, 80(2), 151.

36. Riley, R., and Young, G. (2007). Skill heterogeneity and equilibrium unemployment. Oxford Economic Papers, 59(4), 702-726.

37. Schultze, C. (1999). Downsized and out? The Brookings Review, 17, 9-14.

38. Seitchik, A. (1991). Who are displaced workers? In John T Addison ed. "Job Displacement: Consequences and Implications for Policy" Detroit: Wayne University Press.

39. Simpson, W. (1990). Starting even? Job mobility and the wage gap between young single males and females. Applied Economics, 22, 723-737.

40. Steel, R. P., and Ovaille, N. K. (1984). A review and meta-analysis of research on the relationship between behavioral intentions and employee turnover. Journal of Applied Psychology, 69, 673-686.

41. Steers, R., and Mowday, R. (1981). Employee turnover and post-decision accommodation process: in L. Cummings and B. Staw Research in Organizational Behavior, JAI Press, Connecticut.

42. Tett, R. P., and Meyer, J. P. (1993). Job satisfaction, organizational commitment, turnover intention, and turnover: Path analyses based on meta-analytical findings. Personnel Psychology, 46(2), 259.

43. Van Horn, C. E. (2006). Mega-trends in the American workforce. Human Resource Development Quarterly, 17(4), 475. 
NOTES 